\title{
Is There a Relationship Between Ethmoid Roof Height and Anterior Ethmoidal Artery Trace in Children and Adolescents?
}

\section{Çocuk ve Ergenlerde Etmoid Çatı Yüksekliği ile Ön Etmoidal Arter Trasesi Arasında Bir İlişki Var mı?}

\author{
(1D) Merter Keceli \\ University of Health Sciences, Konya Educational and Research Hospital, Pediatric Radiology Department, Konya, Turkey
}

\begin{abstract}
Aim: The anterior ethmoidal artery course and the depth of olfactory fossa should be determined in paranasal sinus surgery to avoid complications. In this study, the relationship between anterior skull base height and anterior ethmoidal artery (AEA) anatomy was tried to be determined in children and adolescents.

Material and Method: The cranial magnetic resonance imaging of participants between 24 months and 18 years of age, who had no cranial pathology between 2014 and 2018, were re-examined. Of the participants, 101 (50.5\%) were male. The participants were divided into age groups. All measurements were made in the section on the T2-weighted coronal plane images. The AEA's entry points into the nasal cavity were determined. The depth of olfactory fossa was determined according to the line drawn on the medial rectus muscle from the roof.

Results: The depth of olfactory fossa was type II in 97 (48.5\%) of all cases. The AEA entry was on the skull base in 131 cases (65.5\%) on the right and 154 cases (77\%) on the left. In the 25 cases (12.5\%), the AEA entry point was asymmetrical. No significant correlation was found between the depth of olfactory fossa and AEA entry $(p=0.553$ and 0.504$)$.

Conclusion: No relation was found between the depth of olfactory fossa and sex or age. In adults, however, it was found to differ by sex. In MRI examination, the depth of olfactory fossa and the ethmoid roof are not a guide for AEA placement in children, which should be considered to avoid complications during operations.
\end{abstract}

Keyword: Etmoid roof, anterior etmoidal artery, surgical complications, children, imaging
Öz

Amaç: Komplikasyonları önlemek için paranazal sinüs cerrahisinde ön etmoidal arterin seyri ve etmoid çatı yüksekliği belirlenmelidir. Ön kafa tabanı yüksekliği ile ön etmoidal arter (AEA) anatomisi arasındaki ilişki çocuklarda ve ergenlerde belirlenmeye çalışıldı.

Gereç ve Yöntem: 2014-2018 yılları arasında kraniyal patolojisi olmayan 24 ay ile 18 yaş arasındaki katılımcıların kraniyal manyetik rezonans görüntülemeleri yeniden incelendi. Katılımcıların 101'i (\% 50,5) erkekti. Katıımcılar yaş gruplarına ayrıldı. T2 ağırlıklı koronal düzlem görüntüleri üzerinde tüm ölçümler kesitte yapıldı. AEA'nın burun boşluğuna giriş noktaları belirlendi. Çatıdan medial rektus kasına çizilen çizgiye göre etmoid çatı yüksekliği belirlendi.

Bulgular: Tüm vakaların 97'sinde (\% 48.5) Olfaktor fossa derinliği tip II idi. AEA girişi sağda 131 olguda (\% 65.5) ve solda 154 olguda (\% 77) kafa tabanında idi. 25 vakada (\% 12.5), AEA giriş noktası asimetrikti. Ofkator fossa derinliği ve etmoid çatı ile AEA girişi arasında anlamlı bir ilişki bulunmadı ( $p=0.553$ ve 0.504).

Sonuç: Etmoid çatı yüksekliği ile cinsiyet veya yaş arasında bir ilişki bulunamadı. Yetişkinlerde ise cinsiyete göre farklılı gösterdiği görülmüştür. MRI incelemesinde olfaktor fossa derinliği çocuklarda AEA yerleşimi için bir kılavuz değildir ve operasyonlar sırasında komplikasyonları önlemek için dikkate alınması gerekir.

Anahtar Kelimeler: Etmoid çatı, anterior etmoidal arter, çocuk, görüntüleme

Corresponding (illetişim): Merter Keceli, University of Health Sciences, Konya Educational and Research Hospital, Pediatric Radiology Department. Ayanbey, Yeni Meram Cd. No:97, 42090 Meram, Konya, Turkey

E-mail (E-posta): merterkeceli@gmail.com

Received (Geliş Tarihi): 02.09.2020 Accepted (Kabul Tarihi): 31.01.2021 


\section{INTRODUCTION}

Endoscopic sinus surgery (ESS) is a current and reliable approach in the treatment of sinonasal pathology. Due to their close proximity, the relationship between sinonasal structures and eye and cerebral tissue should be known, as well as the possible variations of these structures. ${ }^{[1,2]}$ Thus, patient mortality and morbidity rates can be reduced. It is important to know the anatomy of the anterior skull base and anterior ethmoidal artery (AEA) in order to avoid complications related to ESS. There is a bone boundary between the ethmoid roof and the frontal cranial fossa. During interventions in ESS, the cranial cavity is associated with the nasal cavity if this roof is damaged. Skull base injury can then result in cerebrospinal fluid leakage, pneumocephalus, meningitis, or direct cerebral injury. The classification used in practice and adapted by Keros is aimed at reducing the risk of iatrogenic injury due to ethmoidectomy by determining the anterior skull base height. ${ }^{[3]}$ Yenigun et al. ${ }^{[2]}$ demonstrated that with the increase of the superior-inferior depth and anterior-posterior length and the presence of supraorbital pneumatization, the AEA is significantly more likely to be running freely inside the ethmoidal sinus, thus being more prone to being injured during surgery. With a new anatomical approach, they showed that the length of the cribriform plate is as clinically relevant as the depth, and three-dimensional evaluation is also mandatory. They also reported that knowing the course of the AEA and its relationship with other anatomical structures will reduce the risk of complications. The AEA is an important structure within the ethmoid cavity and its injury can result in significant blood loss and/or orbital hematoma with resultant loss of vision. ${ }^{[4]}$

Although several studies have been reported on the anatomical relationships between the AEA and olfactory fossa depth and ethmoid roof, the results of these studies were mostly obtained from adult patient groups. We concluded that there are not enough studies investigating the existence of a similar relationship in children. The aim of this study was therefore to determine the relationship between the height of the skull base and the location of the AEA in children and to test its usability in order to avoid surgical complications.

\section{MATERIAL AND METHOD}

A retrospective radiologic study was performed by reevaluating the cross-sectional images of pediatric participants without otorhinolaryngologic problems between 2014 and 2018. Images of the participants were taken from the Picture Archiving and Communication System of the hospital. Institutional review board approval from the was obtained prior to data collection of Manisa Celal Bayar University School of Medicine Medical Sciences Ethics Committee (decision dated 02/02/2018 and numbered 20.478.486). All patients sign a document that allows their medical records to be used for scientific studies, provided that their personal information is stored at the time of admission to the hospital. Therefore, the personal consent of the participants was not required.
In the study of Anderhuber et al. ${ }^{[5]}$ It was found that the children under 24 months had low ethmoid roof. In accordance with this conclusion, our study was performed on imaging of children over 24 months of age. Those with primary sinonasal and skull base pathology, history of malignancy, trauma/ surgery, or facial anomalies were excluded. Since there was not a sufficient number of paranasal sinus computed tomography (CT) and magnetic resonance imaging (MRI) results between 2014 and 2018, the bilateral brain MRI scans with detectable AEAs of 200 cases were used.

The participants were divided into age categories of 24-72 months, 73-120 months, 121-168 months, and 169-216 months. The sex distribution was equalized in each determined age group.

The images of the participants had been obtained using a 1.5-T MRI system (Siemens Magnetom Era 1.5 T, Siemens Medical Solutions, USA). The parameters of coronal T2weighted TSE were repetition time (TR) of $3.7 \mathrm{~s}$, echo time (TE) of $80 \mathrm{~ms}$, field of view (FOV) of $200 \mathrm{~mm}$, slice thickness of 3-5 mm, and gap of $1 \mathrm{~mm}$. MRI images of 25-40 coronal sections were obtained according to the slice thickness per case. All scans were examined in T2-weighted coronal plane images by a single pediatric radiologist to assess skull base height and AEA position. Measurements were made at the level of the olfactory sulcus (Figure 1). There is no widely used classification system to determine the olfactory fossa depth or the height of the ethmoid roof in growing children. Therefore, the Keros classification system was modified to determine the the depth of olfactory fossa in children. If level of ethmoid roof did not go down to the upper $1 / 3$ of the medial rectus muscle, it was considered as type I (Figure 2a); if it went down to the upper third of the muscle, as type II (Figure 2b); and if it extended to half of the muscle, as type III (Figure 2c).

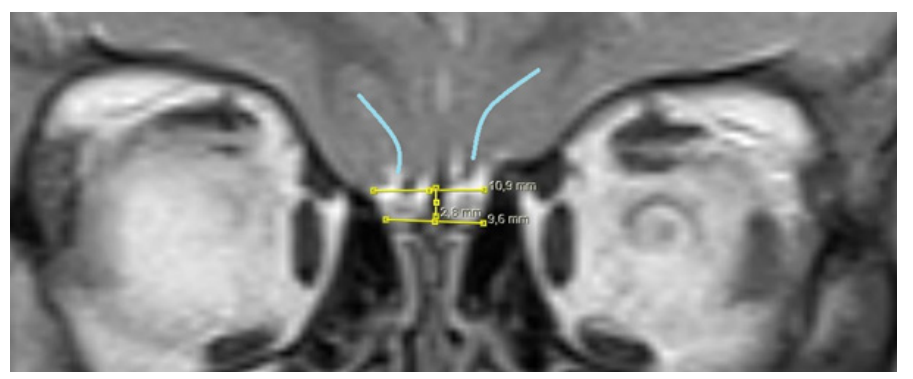

Figure 1. Coronal T2-weighted MR images show ethmoid roof height measurement was made from sections where the olfactory sulcus (blue lines) can be selected.

The AEA's entry point into the nasal cavity was divided into two categories according to locations below and within the front head base (ethmoid roof) (Figure $\mathbf{3 a}$ and $\mathbf{3 b} \mathbf{b}$ ). The asymmetry of the arterial entry points on the right and the left was remarkable. The arterial entry point was recorded accordingly. 

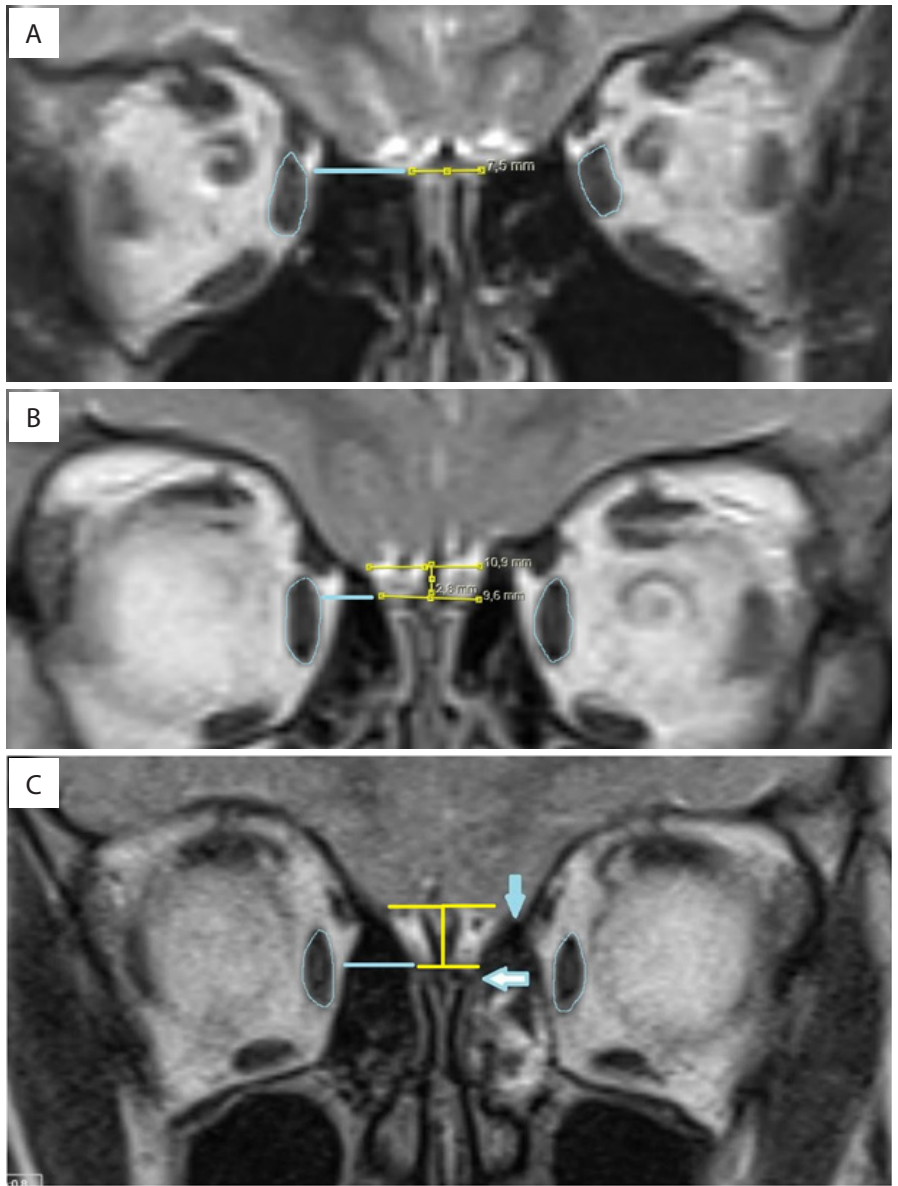

Figure 2. Coronal T2-weighted MR images show that: Type I Ethmoid roof (a): the line drawn from the upper contour of the ethmoid roof (yellow line) does not exceed the upper $1 / 3$ section of the medial rectus muscle blue circles). Type II Ethmoid roof (b): the line drawn from the upper contour of the ethmoid roof (yellow line at the bottom) is at the border of the upper $1 / 3$ of the medial rectus muscle (blue circles). The upper yellow line runs perpendicular to the upper contour of the cribriform plate. Type III Ethmoid roof (c): the line drawn from the ethmoid roof (blue line, open arrow) passes through $1 / 2$ of the medial rectus muscle (blue circles). The closed arrow on the left shows the entry point of the anterior ethmoid artery to the nasal cavity.

The relationships between the depth of olfactory fossa, height of the ethmoid roof and the entry point of the AEA into the nasal cavity and sex and age groups were examined.

All radiographic measurements were performed using the institution's PACS system (Extreme PACS, Ankara, Turkey).

Descriptive statistics of the categorical data in the study were shown by using frequency and percentage values, and numerical data were shown using mean and standard deviation. Kruskal-Wallis non-parametric analysis of variance was used for the comparison of more than two groups and the chi-square test was used for categorical data comparisons. All statistical analyses performed in the study were performed in a two-way, 5\% significance limit and 95\% confidence interval. SPSS 24 for Windows (IBM Corp, USA) was used for data analysis.
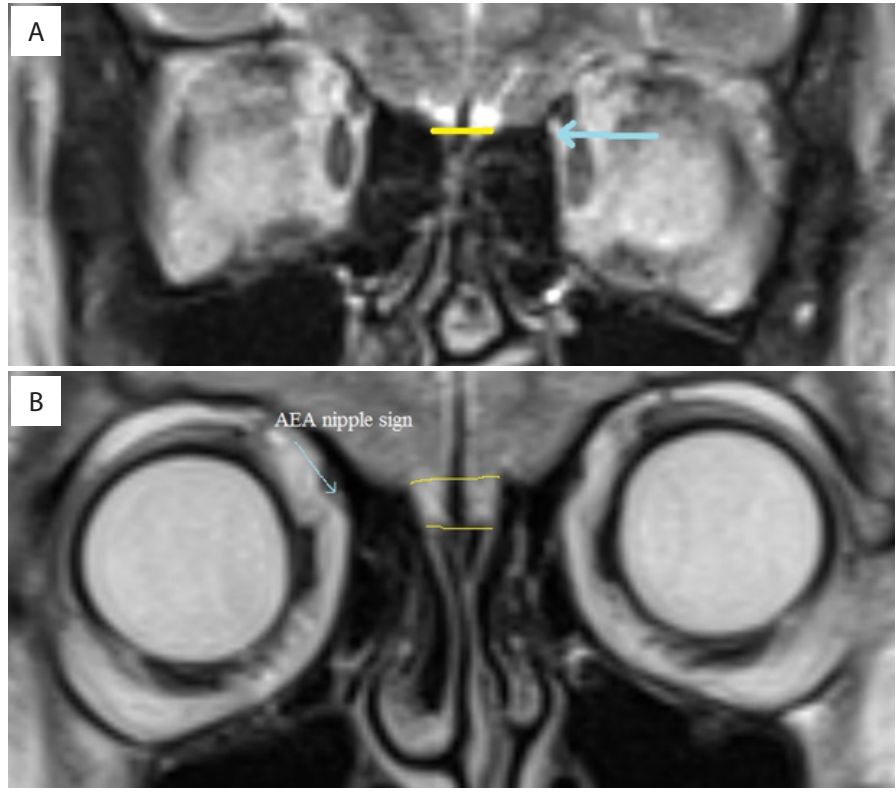

Figure 3. Coronal T2-weighted MR images show that: (a) The entry point of the anterior ethmoidal artery to the nasal cavity (blue line) is at the level of the ethmoid roof (yellow line). (b) The nipple sign showing the entrance point of the anterior ethmoidal artery to the nasal cavity is seen. The entry point is at the top of the ethmoid roof into the nasal cavity.

\section{RESULTS}

Two hundred cranial MRls were included in the study. One hundred and one $(50.5 \%)$ of the participants were male and 99 (49.5) were female. There were 64 participants aged 24-72 months, 51 participants aged 73-120 months, 38 participants aged 121-168 months, and 47 participants older than 169 months. Gender distribution in age groups is shown in Table 1. The mean age was $73 \pm 22$ months irrespective of sex. Regardless of gender, a type I ethmoid fossa depth was found in 92 participants (46\%), type II in 97 participants (48.8\%), and type III in 11 participants (5.5\%) (Table 2 and Figure 4). The distribution of the ethmoid roof height according to the age of the participants is shown in

Table 2 and Figure 5. There was no statistically significant correlation between age group and the ethmoid roof height $(p=0.894)$. No statistically significant correlation was found between the ethmoid roof and gender $(p=0.616)$. Gender distribution for the ethmoid roof types is shown in Table 3 and Figure 6. In 131 cases (65.5\%), the right AEA nasal cavity entry was above the skull base; in 69 cases (34.5\%), it was at the skull base level. In 154 cases (77\%), the left AEA nasal cavity entry was above the skull base; in 46 cases (23\%) it was at the skull base level (Table. 4). There was no statistically significant relationship between the AEA entry points into the nasal cavity and the ethmoid roof height types on both sides ( $p$-value for both sides 0.504-0.553). The relationship between the course of the AEA and the ethmoid roof height shown in Table 5 and Figure 7. 


\begin{tabular}{|c|c|c|c|c|c|}
\hline & & & \multicolumn{2}{|c|}{ Gender } & \multirow{2}{*}{ Total } \\
\hline & & & Female & Male & \\
\hline \multirow{8}{*}{ Age (months) } & \multirow{2}{*}{$\begin{array}{l}24-72 \\
\text { months }\end{array}$} & $\mathrm{N}$ & 25 & 39 & 64 \\
\hline & & $\%$ & $39,1 \%$ & $60,9 \%$ & $100,0 \%$ \\
\hline & \multirow{2}{*}{$\begin{array}{l}73-120 \\
\text { months }\end{array}$} & $\mathrm{N}$ & 23 & 28 & 51 \\
\hline & & $\%$ & $45,1 \%$ & $54,9 \%$ & $100,0 \%$ \\
\hline & \multirow{2}{*}{$\begin{array}{l}121-168 \\
\text { months }\end{array}$} & $\mathrm{N}$ & 20 & 18 & 38 \\
\hline & & $\%$ & $52,6 \%$ & $47,4 \%$ & $100,0 \%$ \\
\hline & \multirow{2}{*}{$\begin{array}{l}169-216 \\
\text { months }\end{array}$} & $\mathrm{N}$ & 33 & 14 & 47 \\
\hline & & $\%$ & $70,2 \%$ & $29,8 \%$ & $100,0 \%$ \\
\hline \multirow{3}{*}{ Total } & & $\mathrm{N}$ & 101 & 99 & 200 \\
\hline & & $\%$ & $50,5 \%$ & $49,5 \%$ & $100,0 \%$ \\
\hline & & & & \multicolumn{2}{|c|}{$\begin{aligned} \text { Chi-Square }=11,320 \\
{ }^{*} p=, 010\end{aligned}$} \\
\hline
\end{tabular}

Table 2. Distribution of ethmoid roof types by age groups regardless of gender.

\begin{tabular}{|c|c|c|c|c|c|c|}
\hline & \multicolumn{3}{|c|}{ Type } & \multirow{2}{*}{ Total } \\
\hline & & & I & II & III & \\
\hline \multirow{8}{*}{$\begin{array}{l}\text { Age } \\
\text { (months) }\end{array}$} & \multirow{2}{*}{$\begin{array}{l}24-72 \\
\text { months }\end{array}$} & $\mathrm{N}$ & 28 & 34 & 2 & 64 \\
\hline & & $\%$ & $43,8 \%$ & $53,1 \%$ & $3,1 \%$ & $100,0 \%$ \\
\hline & \multirow{2}{*}{$\begin{array}{l}73-120 \\
\text { months }\end{array}$} & $\mathrm{N}$ & 24 & 24 & 3 & 51 \\
\hline & & $\%$ & $47,1 \%$ & $47,1 \%$ & $5,9 \%$ & $100,0 \%$ \\
\hline & \multirow{2}{*}{$\begin{array}{l}121-168 \\
\text { months }\end{array}$} & $\mathrm{N}$ & 16 & 19 & 3 & 38 \\
\hline & & $\%$ & $42,1 \%$ & $50,0 \%$ & $7,9 \%$ & $100,0 \%$ \\
\hline & \multirow{2}{*}{$\begin{array}{l}169-216 \\
\text { months }\end{array}$} & $\mathrm{N}$ & 24 & 20 & 3 & 47 \\
\hline & & $\%$ & $51,1 \%$ & $42,6 \%$ & $6,4 \%$ & $100,0 \%$ \\
\hline \multirow{3}{*}{ Total } & & $\mathrm{N}$ & 92 & 97 & 11 & 200 \\
\hline & & $\%$ & $46,0 \%$ & $48,5 \%$ & $5,5 \%$ & $100,0 \%$ \\
\hline & & & & & \multicolumn{2}{|c|}{$\begin{array}{r}\text { Chi-Square }=2,267 \\
{ }^{*} p=, 894\end{array}$} \\
\hline
\end{tabular}

\begin{tabular}{|c|c|c|c|c|c|c|}
\hline & & & \multicolumn{3}{|c|}{ Type } & \multirow{2}{*}{ Total } \\
\hline & & & I & II & III & \\
\hline \multirow{4}{*}{ Gender } & \multirow{2}{*}{ Female } & $\mathrm{N}$ & 43 & 52 & 6 & 101 \\
\hline & & $\%$ & $42,6 \%$ & $51,5 \%$ & $5,9 \%$ & $100,0 \%$ \\
\hline & \multirow{2}{*}{ Male } & $\mathrm{N}$ & 49 & 45 & 5 & 99 \\
\hline & & $\%$ & $49,5 \%$ & $45,5 \%$ & $5,1 \%$ & $100,0 \%$ \\
\hline \multirow{3}{*}{ Total } & & $\mathrm{N}$ & 92 & 97 & 11 & 200 \\
\hline & & $\%$ & $46,0 \%$ & $48,5 \%$ & $5,5 \%$ & $100,0 \%$ \\
\hline & & & & & \multicolumn{2}{|c|}{$\begin{array}{r}\text { Chi-Square }=, 96 \\
{ }^{*} p=, 61\end{array}$} \\
\hline
\end{tabular}

Table 4. The distribution of the ethmoid roof height and anterior ethmoidal artery (AEA) entry points grouping among participants. (1: The AEA enters the nasal cavity above the skull level, 2: The AEA enters the nasal cavity at the level of the skull base, Asym: The AEA entry to the nasal cavity on the right and left is asymmetrical).

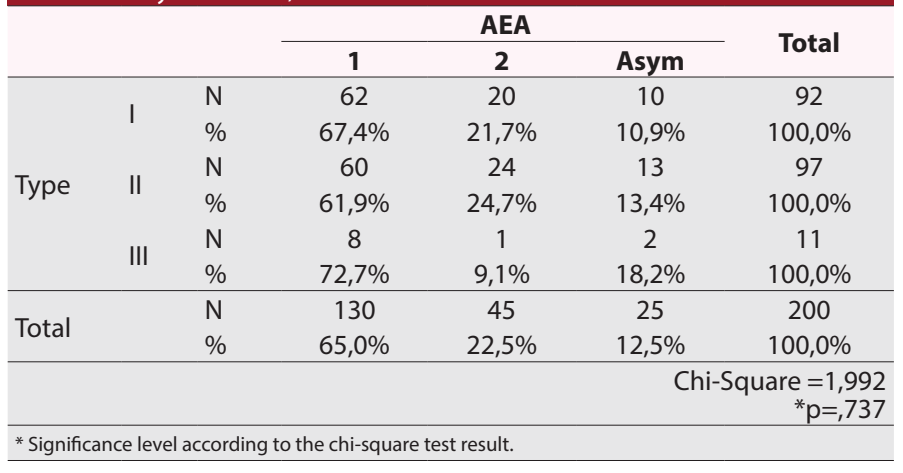

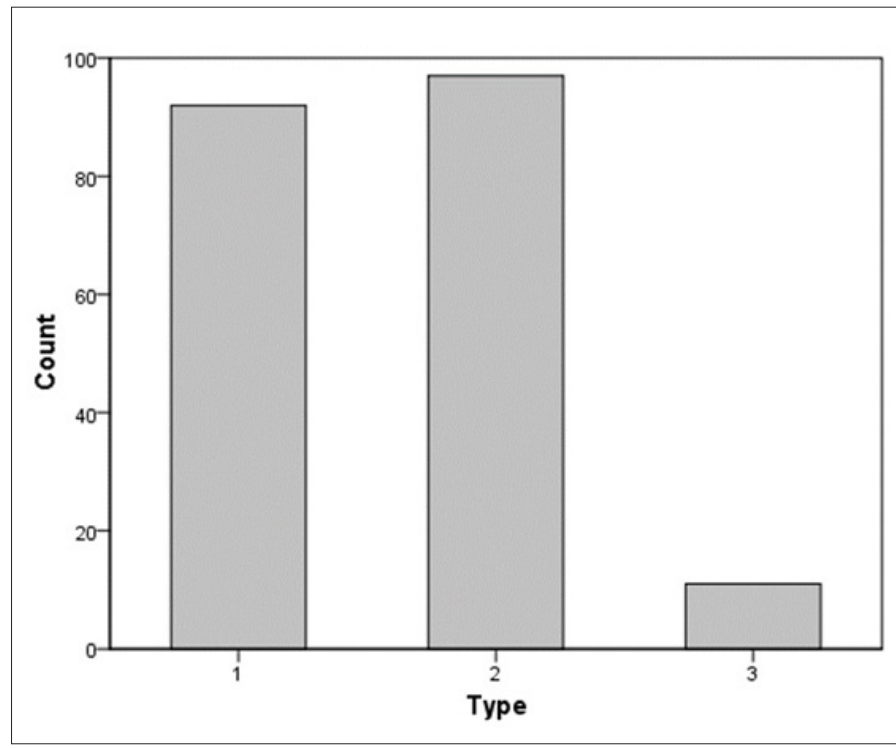

Figure 4. When gender was ignored, the most common type II ethmoid roof was found

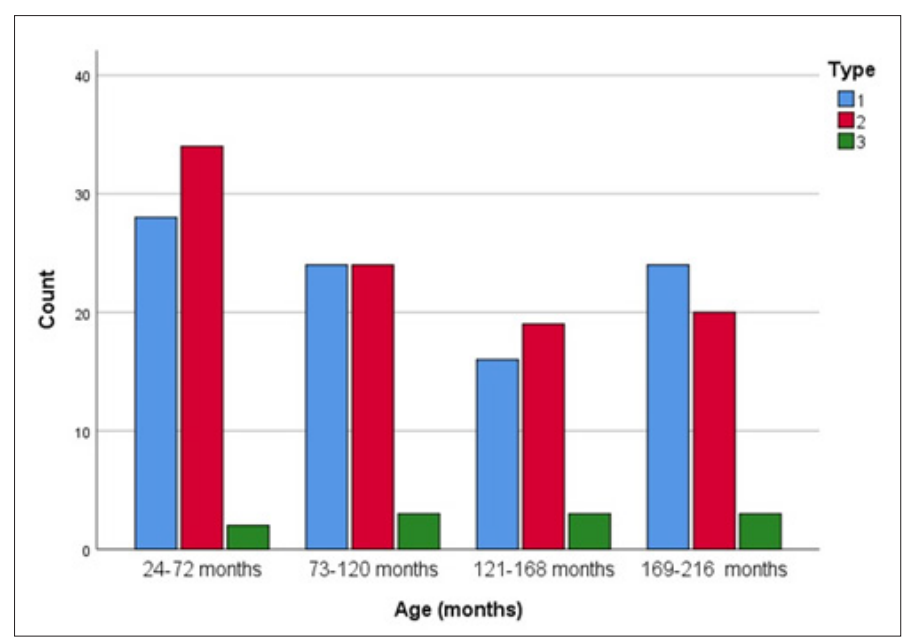

Figure 5. The distribution of ethmoid roof types in age groups

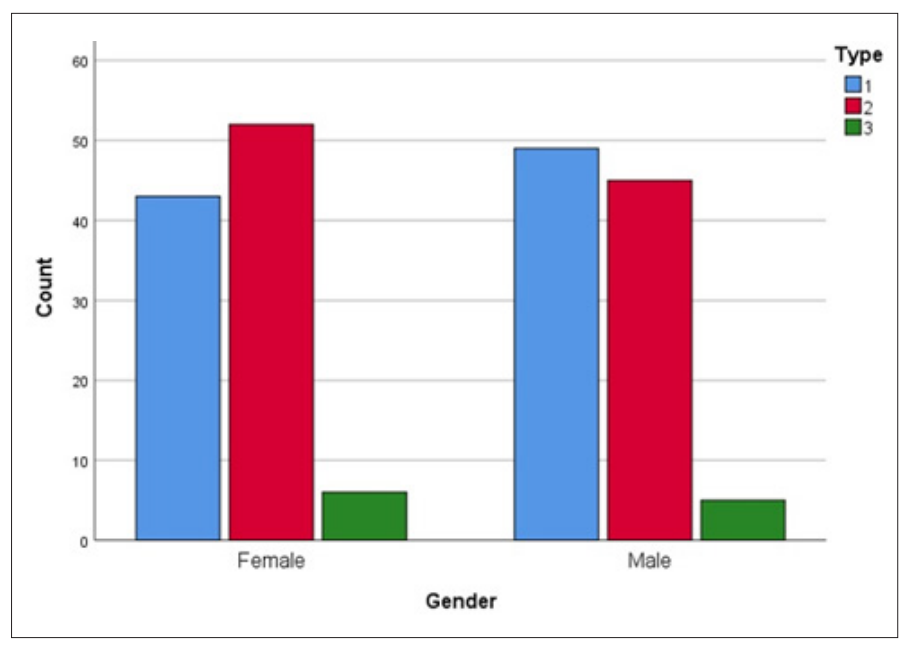

Figure 6. A graphic showing the gender distribution is seen in the ethmoid roof height types 


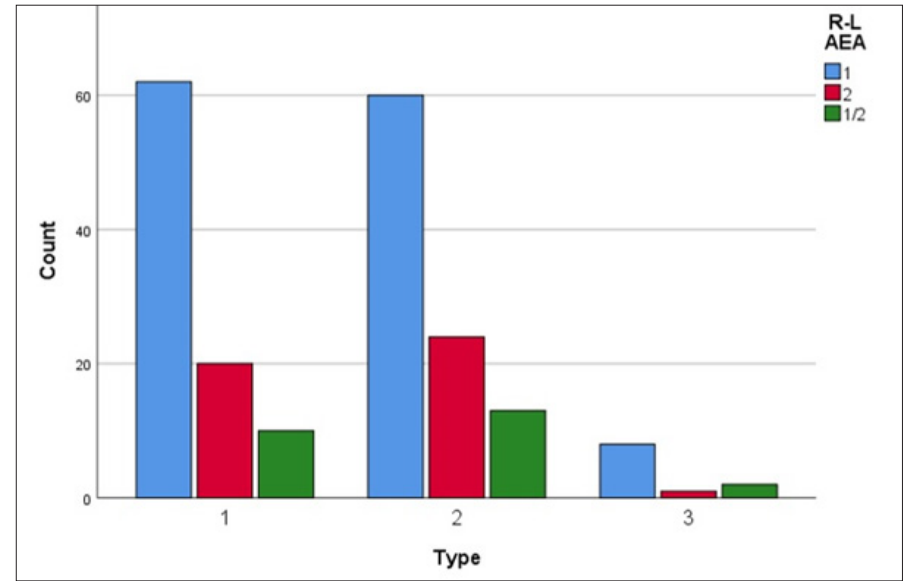

Figure 7. In the graph showing the relationship between the ethmoidal roof classification (Type) and AEA nasal cavity entry points:

It is seen that in all ethmoid roof types, AEA is located on the base of the skull. This is followed by the nasal cavity entry of the AEA from the base of the skull and its asymmetric entrance, respectively.

(Type: Ethmoidal roof height clasification, AEA: Anterior Ethmoidal Artery, blue: The AEA enters the nasal cavity above the skull level.

red: The AEA enters the nasal cavity at the level of the skull base

green: The entry of the AEA to the nasal cavity on the right or left is asymmetrical)

Asymmetry was observed in the course of the AEA in 25 (12.5\%) of 200 cases (Table. 5). Fifteen of these subjects were boys and 12 were girls. The age range was 28-192 months (average: 123 months). When sex was ignored, the ethmoid roof height in these cases was type I in 10 cases, type II in 13 cases, and type III in 2 cases. In cases of asymmetry, 18 right AEAs and 7 left AEAs entered the nasal cavity at the skull base level. There was no statistically significant relationship between asymmetrical AEA entry point into the nasal cavity and the ethmoid roof height $(p=0.737)$ (Figure 8).

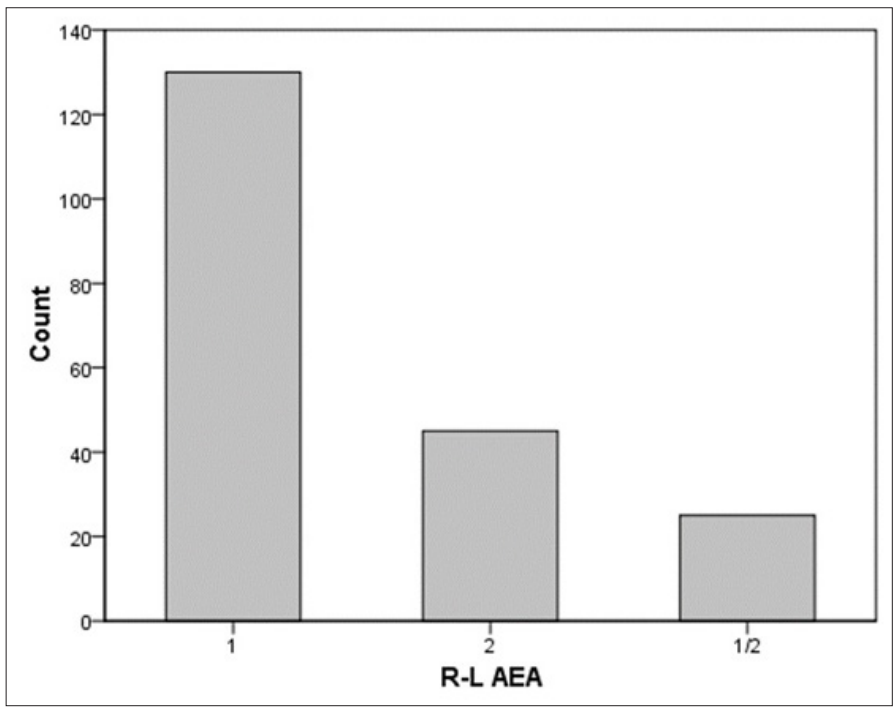

Figure 8. As seen in the graph, the point of entry of the anterior ethmoidal artery (AEA) into the nasal cavity is most often above the level of the skull base
Table 5. There was no statistically significant relationship between the ethmoidal roof types and the anterior ethmoidal artery (AEA) entry points. (1: The AEA enters the nasal cavity above the skull level, 2: The AEA enters the nasal cavity at the level of the skull base, Asym: The AEA entry to the nasal cavity on the right and left is asymmetrical).

\begin{tabular}{llcc} 
& & $\mathbf{N}$ & $\%$ \\
\hline \multirow{2}{*}{ Type } & I & 92 & $46,0 \%$ \\
& II & 97 & $48,5 \%$ \\
& III & 11 & $5,5 \%$ \\
\hline \multirow{2}{*}{ R AEA } & 1 & 131 & $65,5 \%$ \\
& 2 & 69 & $34,5 \%$ \\
\hline \multirow{2}{*}{ AEA } & 1 & 154 & $77,0 \%$ \\
& 2 & 46 & $23,0 \%$ \\
\hline \multirow{2}{*}{ AEA } & 1 & 130 & $65,0 \%$ \\
& 2 & 45 & $22,5 \%$ \\
\hline
\end{tabular}

\section{DISCUSSION}

The Keros Classification, which classifies the depth of olfactory fossa, is used in adult populations. ${ }^{[3]}$ This classification system has become widely adopted and is universally used by surgeons to identify patients with skull base configurations at risk of injury during sinonasal surgery. This system is not suitable for children under 24 months because the ethmoid roof is located more lowly. ${ }^{[5]}$ Many cadaveric and CT imaging studies have shown various landmarks in both adults and children. ${ }^{[6-8]}$ In addition, there are studies investigating the importance of AEA localization as a guide for preventing complications in sinonasal surgery and its relationship with the Keros classification. ${ }^{[9,10]}$ These studies were performed on images of participants from adult groups or without age grouping. In this study, we aimed to investigate the relationship between the,ethmoid roof height and the AEA in the pediatric age group by evaluating participants between the ages of 2 years and 15 years.

According to the modified classification that we applied, the ethmoid roof height was most commonly type II regardless of age. Type III ethmoid roof heightis the least common. This finding is similar to results of applying the Keros classification in adult studies. ${ }^{[9-11]}$ When the age group was not taken into consideration, it was observed that the ethmoid roof height was type I in males and type II in females in both children and adolescents. However, this difference was not statistically significant.

While there are known age-related variations in skull base height and structure, little has been reported on sex differences in skull base anatomy. ${ }^{[12]}$ In Poteet et al. ${ }^{[13] ' s}$ study, men had Keros type II or III significantly more often than women. This confirms the results found in another CTbased study that males more commonly had Keros type II, whereas females more commonly had Keros type I. There are also studies showing that the depth of olfactory fossa varies according to sex in adults. ${ }^{[11,14]}$ According to our data, there was no correlation between type of the ethmoid roof height and sex in children and adolescents. 
In our study, it was observed that the entrance of the AEA into the nasal cavity was not associated with the he ethmoid roof height in children, regardless of age and sex. Başak et al. ${ }^{[10]}$ reported that the course of the AEA is more variant in children than in adults. It has been stated that the reason for this may be the ethmoid cells pushing on the AEA during growth. On the other hand, Poteet et al. showed that patients with variant AEA tracings below the skull base were predominantly males and had type III depth of olfactory fossa according to the Keros classification. They reported that the depth of olfactory fossa, the ethmoid roof may be decisive to show variation in the AEA's path. ${ }^{[9]}$ In our study, it was observed that there was no connection between the course of the AEA and the points of entry into the nasal cavity and the ethmoid roof height among the participants. In addition, in all three types of the ethmoid roof, both AEA nasal cavity entry points were predominantly at the level of the skull base. Unlike studies in adults, there was no guiding link between these landmark points in children and adolescents.

There are two major limitations of our study. First, there was no asymmetric the depth of olfactory fossa and the ethmoid roofs among the participants. However, Anderhuber et al. ${ }^{[5]}$ reported $15 \%$ asymmetry in their participants with similar age and sex distributions. This difference may be due to the fact that in our retrospective study, asymmetric cases were not selected unconsciously when looking for patients with optimal MRI sections for accurate measurements.

In a cadaver study, it was found that the AEA is always adjacent to the basal lamella, but it was not indicated if variations in the basal lamella structure correlated with AEA location. The finding that pneumatization of supraorbital ethmoid cells (SOECS) is consistently a reliable indicator of AEA location is of special interest as SOECs are usually the closest adjacent structures to the AEA in its common course within the skull base. ${ }^{[15]}$ These findings suggest that pneumatization patterns during embryological development influence the AEA's position. In our study, however, we did not include SOEC pneumatization among the examined parameters. The association between SOEC pneumatization and ethmoid roof height could be investigated. In a study in which Yenigun et al. determined a new ethmoid roof classification, the free course of the AEA in ethmoid cells was reported to be surgically dangerous. This rate was $25 \%$ in adults. Therefore, it is stated that the course of the AEA is important in preoperative imaging. ${ }^{[2]} \mathrm{A}$ similar rate was found in Başak et al.'s study of children. ${ }^{[10]}$ In our series, free AEA could not be differentiated between ethmoid cells. This may be due to an inability to select the AEA in the vicinity of the vented ethmoid cells on MRI. This second limitation, which is thought to have been caused by the selected imaging method, can be overcome by extensive CT scans.

\section{CONCLUSION}

During MRI examination of the anterior skull base in children and adolescents, the depth of olfactory fossa and the ethmoid roof are not a guide for the placement of the AEA, which should be considered to avoid complications during the operation. There was no correlation between the height of the ethmoid roof and the entrance point of the AEA into the nasal cavity in growing children. These findings do not match the results obtained in adults. Therefore, we conclude that these findings cannot be used as a surgical guide to prevent complications in children.

\section{ETHICAL DECLARATIONS}

Ethics Committee Approval: Institutional review board approval from the was obtained prior to data collection of Manisa Celal Bayar University School of Medicine Medical Sciences Ethics Committee (decision dated 02/02/2018 and numbered 20.478.486).

Informed Consent: Because the study was designed retrospectively, no written informed consent form was obtained from patients.

Referee Evaluation Process: Externally peer-reviewed.

Conflict of Interest Statement: The authors have no conflicts of interest to declare.

Financial Disclosure: The authors declared that this study has received no financial support.

Author Contributions: Concept, design, data collection and processing, analysis and interpretation, literature review, article writing, critical review, and statistical study were done by Merter Keçeli.

\section{REFERENCES:}

1. Adeel M, Ikram M, Rajput MS, Arain A, Khattak YJ. Asymmetry of lateral lamella of the cribriform plate: a softwarebased analysis of coronal computed tomography and its clinicalrelevance in endoscopic sinus surgery. Surg Radiol Anat 2013;35(9):843-7.

2. Yenigun A, Goktas SS, Dogan R, Eren SB, Ozturan O. A study of the anterior ethmoidal artery and a new classification of the ethmoid roof (Yenigun classification). Eur Arch Otorhinolaryngol 2016;273(11):3759-64.

3. Keros P. On the practical value of differences in the level of lamina cribosa of the ethmoid. Z Laryngol Rhinol Otol. 1962;41:809-13.

4. Stankiewicz JA, Chow JM. Two faces of orbital hematoma in intranasal (endoscopic) sinus surgery. Otolaryngol Head Neck Surg. 1999;120:841-7.

5. Anderhuber W,Walch C, Fock C. Configuration of ethmoid roof in children 0-14 years of age. Laryngorhinootologie. 2001;80(9):509-11.

6. Pernas FG, Coughlin AM, Hughes SE, et al. A novel use of a landmark to avoid injury of the anterior ethmoidal artery during endoscopic sinus surgery. Am J Rhinol Allergy. 2011;25:54-57

7. Souza SA, Sousa MM, Gregorio LC, Ajzen SC. Anterior ethmoidal artery evaluation on coronal CT scans. Braz J Otorhinolaryngol. 2009;75:101-6.

8. McDonald SE, Robinson PJ, Nunez DA. Radiological anatomy of the anterior ethmoidal artery for functional endoscopic sinus surgery. J Laryngol Otol. 2008;122:264-7.

9. Poteet PS, Cox MD, Wang RA, Fitzgerald RA, Kanaan A. Analysis of the Relationship between the Location of the Anterior Ethmoid Artery and Keros Classification. Otolaryngol-Head Neck Surg Aug 2017;157:320-4. 
10. Başak S, Akdilli A, Karaman CZ, Kunt T. Assesment of some important anatomical variations and dangerous areas of the paranasal sinuses by computed tomography in children. Int J Pediatr Otorhinolaringol 2000;55(2):81-9.

11. Muñoz-Leija MA, Yamamoto-Ramos, M, Barrera-Flores FJ et al. Anatomical variations of the ethmoidal roof: differences between men and women. Eur Arch Otorhinolaryngol 2018;275:1831.

12. Gulder C, Zimmermann AP, Diogo I, Werner JA, TeymoortashA. Agedependent differences of the skull base. Int J Pediatr Otorhinolaryngol. 2012;76:822-8.

13. Elwany $S$, Medanni A, Eid $M$, et al. Radiological observations on the olfactory fossa and ethmoid roof. J Laryngol Otol 2010;124:1251-6.

14. Mojas-cavernas I, Garcia-Garrigos E, Arenas Jimenes JJ et al. Radiological anatomy of the ethmoidal arteries: CT cadaver study. Acta Otorrinolaringol Esp. 2011;62:367-74.

15. Jang DW, Lachanas VA, White LC, et al. Supraorbital ethmoid cell: a consistent landmark for endoscopic identification of the anterior ethmoidal artery. Otolaryngol Head Neck Surg 2014;151:1073-7. 